\title{
A inconstitucionalidade parcial do caput do art. 21 da Lei de Mandado de Segurança (Lei no 12.016/2009)
}

Alexandre de Moraes*

O art. 5º, inciso LXX, da Constituição Federal 1988 criou o mandado de segurança coletivo, tratando-se, à época, de grande novidade no âmbito de proteção aos direitos e garantias fundamentais, e que, até recentemente, era disciplinado - "no plano jurídico-processual" - pelos princípios básicos que regem o mandado de segurança individual. ${ }^{1}$

O mandado de segurança coletivo tem por escopo a defesa dos mesmos direitos que podem ser objeto do mandado de segurança individual, porém, direcionado à defesa dos interesses coletivos em sentido amplo, englobando os direitos coletivos em sentido estrito, os interesses individuais homogêneos e os interesses difusos, contra ato e/ou omissão ilegais ou com abuso de poder de autoridade, desde que presentes os atributos da liquidez e certeza.

A criação do legislador constituinte quis facilitar o acesso ao juízo, permitindo que pessoas jurídicas defendam o interesse de seus membros ou associados, ou ainda "da sociedade como um todo", no caso dos partidos políticos, sem necessidade de um mandato especial, evitando-se a multiplicidade de demandas

\footnotetext{
* Doutor e livre-docente em direito constitucional pela Universidade de São Paulo. Professor associado da USP e professor titular da Universidade Presbiteriana Mackenzie. Desde 2007, exerce os cargos de secretário municipal de transportes e secretário municipal de serviços de São Paulo, acumulando ainda as presidências da CET e SPTrans. Foi promotor de justiça de São Paulo (1991-2002), secretário de Estado da Justiça e Defesa da Cidadania (2002-2005) e membro da 1aㅗ composição do Conselho Nacional de Justiça (CNJ), biênio 2005-2007.

${ }^{1}$ Supremo Tribunal Federal, Pleno, MS 21.615-8/RJ, rel. min. Celso de Mello.
} 
idênticas e consequente demora na prestação jurisdicional, e fortalecendo as organizações classistas.

Quanto à legitimidade ativa dos partidos políticos, o texto constitucional estabeleceu a possibilidade de propositura do mandado de segurança coletivo, desde que o partido tenha representação no Congresso Nacional, ou seja, exigindo-se somente a existência de, no mínimo, um parlamentar filiado em qualquer das casas legislativas (Câmara dos Deputados ou Senado Federal), com "a patente finalidade de fortalecimento da vida institucional do país", pela possibilidade de os partidos políticos defenderem em juízo os direitos dos brasileiros.

Recentemente, porém, ao editar a Lei no 12.016/2009, o legislador ordinário restringiu a legitimidade ativa dos partidos políticos, estabelecendo em seu artigo 21 que "o mandado de segurança coletivo pode ser impetrado por partido político com representação no Congresso Nacional, na defesa de seus interesses legítimos relativos a seus integrantes ou à finalidade partidária".

Em outras palavras, o texto legal trouxe clara restrição à utilização do mandado de segurança coletivo pelos partidos políticos, direcionando-o somente à duas hipóteses:

$>$ defesa de seus interesses legítimos relativos a seus integrantes;

$>$ defesa de seus interesses legítimos relativos à finalidade partidária.

Não parece ter agido com acerto o legislador, que adotou antigo posicionamento restritivo do Superior Tribunal de Justiça, ${ }^{2}$ flexibilizado mais recentemente, ${ }^{3}$ que afirmava: ${ }^{4}$

quando a Constituição autoriza um partido político a impetrar mandado de segurança coletivo, só pode ser no sentido de defender os seus filiados e em questões políticas, ainda assim, quando autorizado por lei ou pelo estatuto. Impossibilidade de dar a um partido político legitimidade para vir a Juízo defender 50 milhões de aposentados, que não são, em sua totalidade, filiados ao partido e que não autorizaram o mesmo a impetrar mandado de segurança em nome deles.

A previsão constitucional de legitimidade ativa aos partidos políticos, para ajuizamento de mandado de segurança coletivo, permite a defesa e proteção de direitos coletivos ou difusos ligados à sociedade.

\footnotetext{
2 Segunda Turma, RMS 1.348/MA, rel. min. Américo Luz.

${ }^{3}$ Superior Tribunal de Justiça, $2^{\text {a }}$ Turma, RMS 15.311/PR, rel. min. Eliana Calmon.

${ }^{4}$ Primeira Seção, MS 197/DF, rel. min. Garcia Vieira.
} 
Ora, se todo o poder emana do povo, que o exerce por meio de representantes eleitos ou diretamente, nos termos da Constituição $(\mathrm{CF} / 88$, art. 1o parágrafo único), sendo indispensável para o exercício da capacidade eleitoral passiva (elegibilidade) o alistamento eleitoral (CF/88, art. 14, §3ํ, III), a razão de existência dos partidos políticos é a própria "subsistência do Estado democrático de direito" e da preservação dos direitos e garantias fundamentais. ${ }^{5}$

Nessa esteira de raciocínio, o legislador constituinte pretendeu fortalecê-los concedendo-lhes legitimação para o mandado de segurança coletivo, para a defesa da própria sociedade contra atos ilegais ou abusivos por parte da autoridade pública.

Cercear essa legitimação somente para seus próprios interesses ou de seus filiados é retirar dos partidos políticos a característica de essencialidade em um Estado democrático de direito e transformá-lo em mera associação privada, o que certamente não foi a intenção do legislador constituinte.

Não foi outro o entendimento do Supremo Tribunal Federal, como bem salientado pela ministra Ellen Gracie, ao destacar:

se o legislador constitucional dividiu os legitimados para a impetração do mandado de segurança coletivo em duas alíneas, e empregou somente com relação à organização sindical, à entidade de classe e à associação legalmente constituída a expressão em defesa dos interesses de seus membros ou associados é porque não quis criar esta restrição aos partidos políticos. Isso significa dizer que está reconhecendo na Constituição o dever do partido político de zelar pelos interesses coletivos, independente de estarem relacionados a seus filiados...

Além disso, a ministra afirma "não haver limitações materiais ao uso deste instituto por agremiações partidárias, à semelhança do que ocorre na legitimação para propor ações declaratórias de inconstitucionalidade" e conclui que "tudo o que foi dito a respeito da legitimação dos partidos políticos na ação direta de inconstitucionalidade pode ser aplicado ao mandado de segurança coletivo" ${ }^{6}$

A supremacia absoluta das normas constitucionais e a prevalência dos princípios que regem a República, entre eles a "cidadania" e o "pluralismo político" como seus fundamentos basilares, obrigam o intérprete, especialmente o Poder Judiciário, no exercício de sua função interpretativa, a aplicar não somente "a norma mais favorável à proteção aos direitos humanos", inclusive "aos direitos polí-

\footnotetext{
${ }^{5} \mathrm{CF} / 88$, art. 1ㅇ, V - consagra o pluralismo político como um dos fundamentos da República Federativa do Brasil.

${ }^{6}$ Segunda Turma, RE 196.184/AM; e ainda, Pleno, MS 24.394-5/DF, rel. min. Sepúlveda Pertence.
} 
ticos", mas também eleger em seu processo hermenêutico a interpretação que lhes garanta a maior e mais ampla proteção, e, consequentemente, exigem a inconstitucionalidade, com a respectiva declaração de nulidade parcial, do caput do art. 21 da Lei n⿳0 12.016/2009, no sentido de se excluir a restrição ao objeto do mandado de segurança coletivo ajuizado por partidos políticos tão somente à "defesa de seus interesses legítimos relativos a seus integrantes ou à finalidade partidária". 